\title{
POLA PENGEMBANGAN INDUSTRI GRACILLARIA DI INDONESIA
}

\author{
Agus Heri Purnomo, Yayan Hikmayani, Zahri Nasution dan Hari Eko Irianto")
} \begin{abstract}
ABSTRAK
Makalah ini melaporkan hasil penelitian tahun 2003, yang ditujukan untuk melakukan identifikasi permasalahan dan perumusan pola pengembangan pengusahaan Gracillaria $s p$. di Indonesia. Penggalian masalah dilaksanakan melalui pengumpulan data dan informasi terdokumentasi, survei dan diskusi dengan narasumber yang relevan. Juga dilakukan pengamatan perkembangan biofisik pembudidayaan Gracillaria sp. yang dilakukan bekerjasania dengan petambak. Berdasarkan data yang terkumpul, dilakukan sintesa permasalahan secara deduktif tentang perumusan pengembangan rumput laut Gracillaria $s p$. Hasil kajian menunjukkan bahwa pembudidayaan Gracillaria sp. dapat meningkatkan keuntungan petambak sebesar Rp 6,9-21,3 juta/ha/tahun sekaligus mengatasi masalah pasokan yang dihadapi oleh industri agar. Perkembangan usaha tersebut terkendala oleh kekhawatiran petambak akan terjadinya pasok lebih (oversupply), yang akan diikuti oleh kemerosotan harga jual produk di tingkat produsen. Solusi yang ditawarkan adalah pengendalian produksi melalui manajemen usaha yang dilakukan secara terpadu, yaitu melalui sistem kuota budidaya yang mencakup hanya lokasi-lokasi paling potensial untuk mencapai tingkat produksi total tidak lebih dari kebutuhan pasar. Lokasi-lokasi yang kurang potensial disarankan untuk mengembangkan budidaya Gracillaria sp. dengan fokus pada tujuan alternatif, yaitu untuk perbaikan produktivitas budidaya komoditas lain (bandeng/ udang). Penelitian teknis yang menyangkut hubungan antara kepadatan Gracillaria $s p$. dan produktivitas bandeng atau udang yang dibudidayakan secara tumpangsari disarankan untuk diteliti pula.
\end{abstract}

ABSTRACT: A Design for the development of Gracillaria sp. industry in Indonesia By :
Agus Heri Purnomo, Yayan Hikmayani, Zahri Nasution and Hari Eko Irianto

This paper reports the result of a research conducted in 2003, which is aimed at identification of problems and formulation of a design for the development of Gracillaria sp. industry in Indonesia. Identification of problems was carried out through review of documented information, survey, discussion with relevant resource persons, and observation of biophysical development of Graciliaria sp. culture, which was done in cooperation with brackish waterfarmers. Based on data collected using these approaches, a problem digest was constructed to deduce a potential formula for the the development of Gracillaria sp. The following sums up the primary findings of this research: The culture of Gracillaria sp. may increase annual profit of brackish water farmers by Rp 6.9-21.3 million/ha/year while at the same time mitigate shortage of raw material facing agar industry. In spite of this, the development of Gracillaria sp. industry is potentially constrained by the concerns over excessive supply, which will be followed by a severe cut in the product's producer price. In line with this, a solution proposed through this paper is a coordinated control in the production, which is facilitated by an integrated entrepreneurship, wherein production quotas are given only to those of the most potential locations, to meet a national production level of no greater than what is demanded. Other locations with less potential brackish water plots is recommended to develop Gracillaria sp. culture focusing on an alternative objective, namely improvement of the productivity of other commodities, such as milk fish and shrimp, cultures. This research also points toward another research opportunity, which should be focused on technical aspect, namely those that deal with the density of Gracillaria sp. as related to the productivity of milkfish and shrimp policultured with this seaweed.

KEYWORDS: design, Gracillaria, integrated development

\section{PENDAHULUAN}

Awal dekade 90-an merupakan era kejayaan tambak di Indonesia. Lahan-lahan kurang produktif di berbagai kawasan pesisir, terutama di pantai utara
Pulau Jawa berhasil dikonversi menjadi lahan budidaya udang yang memberikan manfaat ekonomi yang sangat besar bagi banyak pelaku usaha di kawasan tersebut (Taukhid et al., 2001). Pada saat itu, tidak kurang dari 400.000 ha areal tambak merupakan lahan

- Peneliti pada Pusat Riset Pengolahan Produk dan Sosial Ekonomi Kelautan dan Perikanan 
budidaya intensif. Beberapa tahun kemudian, produktivitas lahan-lahan tersebut menurun akibat berbagai masalah pada budidaya udang, sehingga usaha pertambakan menjadi tidak ekonomis. Masalah tersebut antara lain adalah tingginya mortalitas udang, lambatnya pertumbuhan dan serangan penyakit, karena penurunan kualitas lingkungan perairan (Zafran, 1992). Permasalahan yang dihadapi pertambakan sejak tahun 1991 menyebabkan produksi udang windu budidaya terus menurun (Satgas Tambak, 1994). Akibatnya, banyak petambak mengambil keputusan menelantarkan tambak-tambak tersebut.

Dalam perkembangannya, sebagian petambak mencoba mengembalikan produktivitas tambaktambak terlantar melalui usaha budidaya bandeng secara tradisional dan semi intensif. Namun demikian, petani tambak pada umumnya menilai bahwa kinerja usaha tambak bandeng jauh di bawah usaha tambak udang. Berkaitan dengan usaha pengembalian produktivitas tambak-tambak, salah satu alternatif yang perlu dipertimbangkan adalah budidaya Gracilaria sp. Rumput laut yang merupakan bahan baku industri pabrik agar-agar ini memiliki potensi ekonomis yang besar karena luasnya cakupan jenis penggunaan dan pasarnya (Kusnendar, 2002; Ma'ruf, 2002).

Dengan penanaman Gracillaria $s p$., petambak memperoleh kesempatan untuk mendapatkan sumber keuntungan ganda: penurunan biaya produksi dan penerimaan dari hasil produksi bandeng dan udang, serta tambahan penerimaan yang diperoleh dari pemanenan rumput laut.

Dari sisi kepentingan industri pengolahan agar, pengembangan Gracillaria sp. sangat diharapkan. Ini karena kebutuhan bahan baku agar, yaitu Gracillaria sp., masih jauh dari terpenuhi (Anun., 2003). Kebutuhan nasional saat ini adalah sebesar 7.170 ton bahan baku kering/tahun, dengan kecenderungan meningkat dari waktu ke waktu. Kebutuhan tersebut diprediksikan akan terus meningkat sehubungan dengan berkembangnya bentuk pemanfaatan produk berbasis agar. Penelitian ini bertujuan melakukan identifikasi permasalahan dan merumuskan pola pengembangan pengusahaan Gracillaria $s p$. di Indonesia, yaitu pola pengembangan yang dapat diharapkan mengarah pada industri yang optimal.

\section{METODE}

Pengumpulan data dan informasi mengenai potensi dan permasalahan yang dihadapi oleh pengusaha rumput laut Gracillaria sp. di beberapa lokasi dilaksanakan melalui survei yang dikombinasikan dengan pendekatan partisipatif, melalui wawancara menggunakan kuesioner terhadap responden yang dipilih berdasarkan informasi dari Dinas Perikanan setempat, yang dipadu dengan proses konfirmasi dan dekonfirmasi dengan narasumber pendukung. Narasumber dimaksud adalah antara lain petambak, Pejabat Kantor Cabang Dinas, Pejabat Dinas Kabupaten/Kota, pengusaha pengolah, dan petambak. Di samping itu, dilakukan pengamatan selama 60 hari terhadap perkembangan biofisik pembudidayaan Gracillaria sp. pada 6 petak tambak milik pembudidaya udang/bandeng, yang oleh pemiliknya ditanami masing-masing $500 \mathrm{~kg}$ Gracillaria yang berasal dari lokasi di Bekasi (dipasok oleh Unit Usaha Balai Inkubator Badan Pengkajian dan Penerapan Teknologi).

Dalam pengamatan di lahan-lahan tambak Gracillaria sp., dicatat perkembangan variabel teknoekonomis yang meliputi masukan yang terkait dengan usaha pembudidayaan polikultur bandeng-udangrumput laut (penyiapan lahan, pengadaan benih udang dan bandeng, pembelian bibit rumput laut, pemanenan, dan pengeringan rumput laut), dan hasil yang diperoleh (penjualan udang, bandeng, rumput laut, dan harga yang berlaku). Dalam pengamatan tersebut, perkembangan variabel biofisik yang mencakup suhu, oksigen terlarut, salinitas, kecerahan, kadar fosfat, logam berat, dan kadar nitrat dicatat.

Riset biofisik dilaksanakan pada petak-petak lahan di Desa Muara Baru, Kecamatan Cilamaya dan petambak Desa Pedes, Kecamatan Rengasdengklok, Kabupaten Karawang. Riset potensi dan kondisi sosial ekonomi dilaksanakan pada beberapa lokasi untuk menggambarkan keragaman kondisi tersebut yaitu di wilayah Propinsi Lampung (Labuhan Maringgai, Lampung Timur), wilayah Pantai Utara Jawa seperti Karawang, Serang, Indramayu, Pemalang dan Sulawesi Selatan (Palopo dan Takalar).

Data yang terkumpul melalui pendekatanpendekatan tersebut, digunakan untuk mensintesa permasalahan untuk secara deduktif mengambil kesimpulan tentang rumusan pengembangan Gracillaria sp. Dalam hal ini, pengusahaan Gracillaria sp. di berbagai lokasi secara deskriptif diperbandingkan berdasarkan kinerja dan variablelvariabel yang melingkupinya untuk mengidentifikasi variabel yang diperkirakan berpengaruh terhadap keberhasilan atau kegagalan pengusahaan Gracillaria sp. Berdasarkan itu, diprediksikan hal yang akan terjadi akibat penerapan manajemen pengembangan tertentu. Kesimpulan yang berupa rumusan tentang pola pengembangan Gracillaria $s p$. ditarik dari pembahasan yang didasarkan pada prediksi-prediksi tersebut. 


\section{HASIL DAN BAHASAN}

Bagian berikut memaparkan fakta-fakta yang mencerminkan status pengusahaan, problematika, dan faktor-faktor spesifik yang melingkungi pengusahaan Gracillaria sp. di wilayah-wilayah sentra dan atau wilayah potensial budidaya Gracillaria sp. di Indonesia. Rangkuman fakta-fakta spesifik ditampilkan untuk menonjolkan keragaman lokasi dalam hal potensi lahan usaha, profitabilitas, peran pemerintah, dan tantangan pemasaran Gracillaria sp. di berbagai tempat. Lokasi kajian mencakup kasus-kasus Karawang (Jabar), Palopo (Sulsel), Takalar (Sulsel), Lampung Timur (Lampung), Pemalang (Jateng), dan Bekasi (Jabar).

\section{Sintesa Permasalahan Pengembangan Gracillaria sp. di Indonesia}

\section{Permasalahan pengembangan usaha Gracillaria sp. di berbagai lokasi terpilih}

Areal tambak di Kabupaten Karawang pada tahun 1999 tercatat seluas $12.336,29$ ha, yang berpotensi untuk penanaman Gracillaria sp.. Dari total luasan tersebut, saat ini sejumlah $1.648,80$ ha dimanfaatkan untuk budidaya udang sedangkan sisanya digunakan untuk budidaya bandeng secara tradisional. Ujicoba penanaman Gracillaria sp. (yang ditumpangsarikan dengan bandeng) pada lahan tambak telah dilakukan pada tahun 2002 di dua kecamatan, yaitu 2 ha di Cilamaya dan 3 ha di Rengasdengklok. Dari pengamatan biofisik dan sosial ekonomi selama 4 bulan, disimpulkan bahwa penanaman rumput laut tersebut memberikan hasil awal yang baik. Analisis usaha menunjukkan adanya tambahan keuntungan kepada petambak sebesar Rp 1.436.000/ha (keuntungan tumpang sari bandeng-Gracillaria $s p$. adalah Rp3.470.000/ha/4bulan, dibanding dengan hanya Rp2.034.000/ha/4bulan pada budidaya bandeng).

Terlepas dari besarnya luasan lahan yang tersedia dan gambaran keuntungan yang dapat diciptakan oleh petambak, penanaman Gracillaria sp. di Karawang belum berkembang. Penelitian ini mengidentifikasi dua hal menonjol yang terkait dengan hal ini, yaitu: (1) ketiadaan data rinci tentang kualitas lahan tambak di masing-masing lokasi, dan (2) kurangnya contoh nyata tentang peluang keberhasilan budidaya Gracillaria sp. di wilayah tersebut. Sebagaimana teramati dalam penelitian ini, bahkan untuk cakupan lokasi yang terbatas, variasi salinitas dari petak-petak tambak ternyata cukup besar. Salinitas pada salah satu petak berada pada kisaran 35-37 permil sedangkan pada petak lain di kawasan yang sama salinitas dapat mencapai 45-50 permil. Pada kasus tersebut, perbedaan salinitas terkait dengan ketersediaan akses terhadap pasokan air tawar, yang pada kasus ini identik dengan kedekatan tambak dengan aliran sungai, yang dapat diandalkan oleh petambak untuk menormalkan salinitas yang terlalu tinggi. Informasi mengenai hal-hal tersebut sangat terbatas sehingga besarnya luasan lahan yang tersedia belum cukup memberikan motivasi bagi pemilik modal untuk melakukan investasi pada usaha Gracilaria $s p$. Sementara itu, petambak, yang dapat mengambil keuntungan dari tumpangsari Gracillaria sp. untuk memperbaiki produksi udang atau bandengnya, belum mendapatkan informasi yang cukup tentang manfaat keberadaan Gracillaria sp. dalam tambak udang/ bandeng.

Berbeda dengan Karawang, pengusahaan Gracillaria sp. di Kota Palopo (Sulsel), berkembang dengan lebih baik meskipun ketersediaan lahan tambak di Palopo tidak sebesar yang dimiliki oleh Kabupaten Karawang. Areal pertambakan seluas 1.510 ha di Palopo sebagian besar (998,25 ha) diusahakan untuk penanaman Gracillaria sp. yang ditumpangsarikan dengan bandeng atau bandeng dan udang, dan hanya sebagian kecil yang diusahakan secara monokultur untuk budidaya udang windu. Analisis usaha yang dilakukan dalam penelitian ini menunjukkan bahwa keuntungan yang diperoleh 221 petambak yang mengusahakan lahan-lahan tersebut cukup besar. Berdasarkan data dari 20 orang responden, keuntungan yang diraih oleh petambak rata-rata mencapai Rp. 23,6 juta/ha/tahun, yang berasal pemanenan Gracillaria sp. yang dilakukan dari 8 kali per tahun dan pemanenan bandeng atau udang yang dilakukan sekali setahun.

Perkembangan positif yang berhasil dicapai dalam pengusahaan Gracillaria sp. di Palopo sejalan dengan keberadaan beberapa faktor pendukung, yaitu: sosialisasi dan dukungan aktif pemerintah daerah dan berfungsinya lembaga pemasaran yang mampu menjaga kestabilan harga. Dukungan aktif pemerintah misalnya tercermin dari adanya nota kesepahaman antara Pemerintah Kota dengan perusahaan swasta, untuk mendukung kerjasama saling menguntungkan antara pembudidaya dengan perusahaan penampung produksi Gracillaria sp. Dukungan aktif tersebut juga memperkuat kinerja kelembagaan pemasaran yang pada dasarnya telah berfungsi secara baik. Pada saat ini selain menampung produk dari dalam wilayah, pengusaha pengumpul di Kota Palopo juga berhasil memposisikan diri sebagai simpul pemasaran penting bagi produk-produk yang berasal dari kabupatenkabupaten di sekitarnya. Pada saat penelitian ini dilakukan, 13 pedagang pengumpul dengan kapasitas tampung 4-20 ton/hari, memperagakan fungsi aktif dalam mendukung kelancaran pemasaran hasil 
budidaya petambak Gracillaria sp. di Palopo dan sekitarnya. Pedagang pengumpul ini menjalin hubungan erat dengan pengguna langsung di dalam negeri, yaitu pabrik agar-agar di Malang, Surabaya, dan Tangerang dan para eksportir di Makassar dan Medan, yang melakukan pengiriman ke target-target pasar internasional di luar negeri.

Kasus Takalar memperkaya pelajaran yang dapat dipetik dari pengusahaan Gracillaria sp. di Palopo, terutama dalam hal identifikasi faktor yang umumnya berpengaruh pada kinerja dari industri tersebut. Meskipun memiliki faktor pendukung seperti pada kasus Palopo, profitabilitas dan perkembangan pengusahaan Gracillaria sp. di Takalar tidak sebaik di Palopo. Di Takalar, jumlah petambak menurun pada tahun terakhir meskipun sempat menunjukkan indikasi positif pada awal perkembangannya.

Dengan lahan potensial seluas 1400 ha lebih, budidaya Gracillaria sp. di Kabupaten Takalar baru dilaksanakan pada areal seluas 220 ha, yaitu di Kecamatan Mangarabombang dan Kecamatan Mappakasunggu. Dari sisi teknis, budidaya Gracillaria $s p$. di Takalar memiliki kesamaan dengan yang terdapat di Palopo, yaitu dalam hal ketersediaan areal penanaman, penerapan tumpangsari dengan udang/bandeng dan dalam hal ketiadaan peremajaan tanaman selama jangka waktu yang ditentukan. Dengan demikian, sebenarnya terdapat peluang yang paling tidak sama besar dengan Palopo, apalagi petambak Takalar pada umumnya memiliki keunggulan dalam hal penerapan teknologi yang terkait dengan aplikasi pupuk (urea dan TSP) dan pengaturan air tambak ( $50 \%$ air tambak diperbarui setiap dua hari sekali dengan memasukkan air laut baru melalui mekanisme buka-tutup pintu pasang surut).

Kesamaan lain dari pengusahaan Gracillaria sp. di Takalar dan Palopo adalah dalam hal jalinan usaha antara petani dengan pedagang pengumpul. Setiap pedagang pengumpul terhubung dengan pemasok Gracillaria $s p$. dari petani tertentu. Dari pedagang pengumpul, Gracillaria sp. asal Takalar dikirim ke para eksportir di Makassar. Seperti yang diberlakukan kepada pemasok dari Palopo, eksportir Makassar menetapkan harga Gracillaria sp. dari para pengumpul asal Takalar berdasarkan hasil pemeriksaan sampel produk di laboratorium milik eksportir. Selain adanya saling ketergantungan, komunikasi bisnis antara petambak dengan para pengumpul di Takalar lancar karena banyak pengumpul berdomisili dan bertransaksi langsung di sekitar lokasi produksi.
Sisi negatif yang berpotensi menjadi kendala perkembangan Gracillaria sp. di Takalar adalah ketidakstabilan harga dan kelangkaan bibit berkualitas. Di Palopo, komitmen Pemda dalam bentuk nota kesepahaman dengan pengusaha berhasil memperkecil gejolak harga pada tingkat petambak dan hal ini tidak terjadi di Takalar. Karena variabel lain menunjukkan kemiripan, satu hal yang paling mungkin adalah bahwa faktor komitmen Pemda telah berperan menyebabkan terjadinya perbedaan antara kinerja pengusahaan Gracillaria sp. di Palopo dan Takalar. Masalah ini diperberat dengan kurangnya akses petambak terhadap sumber pemasok bibit, yang diperlukan untuk mempertahankan produktivitas. Laporan Dinas Perikanan Takalar menunjukkan bahwa gejolak harga dan penurunan produktivitas yang terjadi, secara simultan telah memunculkan disinsentif bagi sebagian petambak; akibatnya, pada saat penelitian jumlah petambak menurun sebesar $15.32 \%$ dibanding jumlah pada tahun sebelumnya.

Terlepas dari masalah yang muncul, keberhasilan pengusahaan Gracillaria sp. di berbagai tempat, termasuk Takalar dan Palopo, telah mendorong wilayah lain, termasuk di antaranya Lampung Timur dan Pemalang, melakukan uji coba pengembangan usaha serupa. Di Lampung Timur, uji coba pertama budidaya Gracillaria sp. dilakukan pada tahun 2002 di Kecamatan Labuhan Maringgai oleh Dinas Perikanan setempat, bekerjasama dengan sebuah perguruan tinggi. Sementara itu, uji coba di Pemalang dilakukan oleh petambak di Desa Pesantren, Kecamatan Ulujami, dengan bimbingan teknis dari sebuah institusi riset nasional. Uji coba di kedua wilayah tersebut belum memberikan gambaran yang sempurna tetapi telah menampakkan beberapa indikasi positif pada sisi teknis.

Dengan perawatan yang lebih baik, dua di antara 8 petak uji coba menggunakan pola tumpangsari dengan bandeng dan udang, yang dilakukan di Labuhan Maringgai. Lampung Timur menunjukkan hasil yang positif, dimana dalam tempo 4 bulan Gracillaria $s p$. yang ditanam berkembang dua ${ }^{1}$ kali lipat dari berat bibit yang dipergunakan. Dalam uji coba tersebut, diterapkan beberapa komponen paket teknologi budidaya udang/bandeng, termasuk pengangkatan lumpur, pengapuran, dan penggunaan pupuk (urea). Penebaran benih udang (5.000 ekor/ ha) dan bandeng (250 benih berukuran $8-10 \mathrm{~cm}$ ). dilakukan secara bersamaan pada saat 30 hari setelah penebaran bibit Gracillaria $s p$. Berat Gracillaria $s p$.

\footnotetext{
Untuk monokultur Gracillaria sp., usaha ekonomis dicapai apabila hasil panen minimal $3 x$ dari bibit yang ditanam; dalam hal tumpangsari, hasil panen seberat $2 x$ dari berat bibit yang ditebar dapat dikatakan cukup baik karena hasil ini hanya merupakan tambahan penghasilan terhadap budidaya bandeng/udang
} 
yang diperoleh pada pemanenen pertama ( 4 bulan) adalah sebesar 2 kali dari berat bibit yang ditanam. Sementara itu, pada saat 2 bulan setelah penebaran, diperoleh panen udang dan bandeng sebesar masingmasing $125 \mathrm{~kg}$ dan $150 \mathrm{~kg}$. Hasil analisis menunjukkan bahwa keuntungan dari usaha budidaya tersebut adalah Rp.6.382.500.- /ha/4 bulan (STTP, 2002)

Berdasarkan wawancara dengan petambak peserta uji coba, tantangan terbesar dalam pengembangan usaha Gracillaria sp. di Lampung Timur adalah kekhawatiran petambak akan terjadinya masalah pasok lebih seperti terjadi sebelumnya terhadap usaha budidaya rumput laut jenis Eucheuma cottonii. Mengacu pada pengusahaan E. cottonii, petambak memperkirakan bahwa pada aspek pemasaran, usaha Gracillaria $s p$. akan menemui kemudahan dan kesulitan yang serupa dengan usaha E. cottonii. Dengan dukungan kelembagaan yang ada, pemasaran E. cottonii mencapai puncak pada tahun 97/98. Sebagian besar kegiatan pemasaran, yang pada umumnya ditujukan untuk memenuhi permintaan luar negeri, terhenti karena jatuhnya harga $E$. cottonii. Saat ini, pemasaran $E$. cottonii hanya dilakukan untuk target lokal dan antar propinsi. Separuh dari lembaga pemasaran yang pada waktu lalu memfasilitasi kegiatan ekspor, hingga saat ini masih menjalankan sebagian fungsinya dengan cukup baik untuk memfasilitasi pemasaran E. cottonii lokal atau antar propinsi. Separuh lainnya beralih fungsi untuk mendukung pemasaran sarang burung, bentuk usaha baru yang berkembang seiring dengan jatuhnya usaha tambak udang. Sejauh ini, hasil wawancara menunjukkan bahwa petambak masih belum cukup teryakinkan bahwa kegagalan serupa tidak harus terjadi pada usaha Gracillaria $s p$. Hal ini terutama karena banyak daerah lain yang tengah mempertimbangkan untuk mengembangkan usaha Gracillaria sp

Perkembangan lebih positif terungkap pada saat akhir dari pelaksanaan penelitian ini. Dengan dukungan lebih besar yang diberikan oleh pemerintah setempat, petambak menunjukkan peningkatan apresiasi terhadap usaha pengembangan budidaya Gracillaria $s p$. di wilayah tersebut. Dukungan positif tersebut tertuang dalam kontrak kerjasama antara pemerintah setempat dengan swasta dan para petambak. Oleh petambak, hal ini dipandang sebagai peluang untuk mengurangi resiko usaha karena ada jaminan yang lebih besar dari swasta dalam hal pemasaran hasil. Apresiasi tersebut bertambah besar dengan adanya penyediaan modal bergulir dari pemerintah bagi petambak untuk melaksanakan usaha rintisan. Selang waktu yang terbatas belum cukup untuk dijadikan dasar menyimpulkan hubungan antara permasalahan dan tindakan yang terkait dengan pengembangan budidaya Gracillaria sp. di Lampung. Sejauh ini terdapat indikasi bahwa sebagian permasalahan telah mulai tertanggulangi oleh adanya faktor dukungan pemerintah setempat. Indikasi tersebut misalnya tercermin dari masih berlanjutnya penanaman oleh petambak yang dijadikan kooperator dalam uji coba.

Berbeda dengan Lampung Timur, uji coba yang terjadi di Pemalang telah mencapai tahap yang lebih lanjut, tetapi perkembangan terakhir justru kurang positif. Uji coba yang dimulai pada Tahun 2002 tersebut dilaksanakan secara komersial berdasarkan kesepakatan kerjasama bisnis antara Balai Pengkajian dan Penerapan Teknologi (BPPT) dengan kelompok petambak di Desa Pesantren, Kecamatan Ulujami, yaitu Kelompok Tani Mitra Bahari. Dalam hal ini, BPPT berperan sebagai pemasok dana, teknologi, dan bibit, sekaligus penampung dari hasil produksi; sementara itu, petambak menyediakan lahan dan tenaga kerja. Secara teknis ujicoba budidaya berjalan tanpa kendala atau masalah yang berarti. Dari aspek sosial pun, penelitian ini mencatat fakta yang positif, dimana petambak menunjukkan minat yang tinggi terhadap budidaya Gracillaria sp. di lahan tambak budidaya udang atau bandeng.

Namun demikian, masalah ekonomis menyebabkan terhentinya sebagian dari usaha tersebut: Dari 50 ha lahan yang diusahakan, pada saat penelitian tersisa hanya 4 ha. Permasalahan yang menyebabkan perkembangan negatif ini adalah ketidakpastian pasar dan harga. Penjualan hasil hanya mengandalkan keberadaan pemilik modal yang telah memberikan modal investasi dan modal kerja pada awal usaha. Hubungan kerja ini berlangsung tanpa penjaminan sebagaimana terjadi pada contoh kasus Lampung. Akibatnya, petambak dalam posisi yang lemah dalam masalah penentuan harga.

Kasus terakhir yang dijadikan sampel adalah pengusahaan Gracillaria sp. di Bekasi. Di lokasi ini, budidaya rumput laut jenis tersebut dimulai pada tahun 2001, di Kecamatan Babelan. Dibandingkan dengan contoh-contoh kasus sebelumnya, contoh kasus Bekasi. Ini dapat dikatakan merangkum faktor-faktor yang seharusnya ada dalam setiap pengusahaan Gracillaria sp. di tempat-tempat lain. Selain dukungan faktor biofisik dan penerapan teknologi budidaya secara benar (pengaturan salinitas, pemupukan teratur sesuai kebutuhan, dsb), usaha Gracillaria sp. di Bekasi berkembang karena kerjasama yang baik, terutama dengan perusahaan swasta yang berfungsi sebagai penampung Gracillaria sp. kering untuk diolah menjadi berbagai bahan makanan dan obat.

Dalam kasus Bekasi, tercatat pula manfaat tambahan yang diperoleh petambak selain dari 
penjualan Gracillaria sp.. Manfaat tersebut berupa perbaikan pertumbuhan udang dan bandeng yang ditumpangsarikan. Penanaman Gracillaria sp. pada tambak tumpangsari telah memungkinkan udang yang dibudidayakan tanpa pemberian pakan alami bertahan hidup sampai 8 bulan untuk mencapai berat $200 \mathrm{gr} /$ ekor, panjang badan diatas $40 \mathrm{~cm}$. Sementara itu, bandeng dapat tumbuh mencapai ukuran 25-30.

Rangkuman dari hasil identifikasi masalah di lokasi-lokasi usaha Gracillaria sp. tersebut di atas dapat dilihat pada Lampiran 1, yang menampilkan matriks yang menggambarkan keterkaitan antara kinerja pengusahaan Gracillaria di berbagai lokasi dan faktor-faktor yang melingkunginya ${ }^{2}$. Sebagaimana terlihat pada lampiran tersebut, kesimpulan yang dapat ditarik adalah bahwa permasalahan umum yang menghadang perkembangan pengusahaan Gracillaria sp. di Indonesia mencakup: jaminan pemasaran (yang terkait dengan kerjasama antara petambak dengan industri pengolah /eksportir, dan kebutuhan pasar) dan penanganan tantangan biofisik (terkait dengan aplikasi teknologi). Bahasan mengenai kebutuhan pasar dan relevansi pengendalian produksi akan dibahas pada bagian berikut dalam laporan hasil penelitian ini.

\section{Relevansi pengendalian produksi Gracillaria sp.}

Keberhasilan pengembangan indutri Gracillaria di Indonesia tidak akan terlepas dari penyesuaian tingkat produksi total dengan kebutuhan pasar, baik internasional maupun domestik. Kasus yang terjadi pada pengembangan Eucheuma cottonii merupakan referensi yang baik untuk membangun strategi pengembangan usaha Gracillaria sp. Berawal dari prediksi tentang potensi produksi yang besar, pada saat itu pengembangan budidaya Eucheuma cottonii dilakukan secara besar-besaran, tanpa disadari bahwa beberapa tahun setelahnya pengembangan tersebut berakibat pada terjadinya pasok lebih dan kejatuhan harga produk. Salah satu contoh konkret adalah kemunduran usaha Eucheuma cottonii di Lampung, yang telah memunculkan keraguan di kalangan petambak setempat untuk mengembangkan Gracillaria sp.

Fakta menunjukkan bahwa dilihat dari sisi potensi produksi maupun aspek pasarnya, secara umum Indonesia berpeluang memainkan peran penting dalam industri rumput laut dunia. Dari sisi produksi, kekuatan tersebut terkait dengan besarnya variasi jenis rumput laut yang dimiliki, sebaran geografisnya, maupun kecocokan iklimnya. Dari 555 jenis rumput laut yang ada di Indonesia, empat jenis diantaranya telah berkembang secara komersial, yaitu Eucheuma, Gracillaria, Gelidium dan Sargassum, baik untuk pasar lokal maupun internasional. Negara-negara pengimpor rumput laut Indonesia adalah di antaranya: Jepang, Hongkong, Korea Selatan, USA, Inggris, Perancis, Denmark, Spanyol, Taiwan, China, Malaysia dan Chilli. Permintaan internasioanal meningkat $10 \%$ /tahun (Wahyuni, 2003).

Sisi negatif dari industri rumput laut Indonesia adalah bahwa sejauh ini kegiatan ekspor, termasuk jenis Gracillaria sp., terbatas pada bahan mentah, yaitu rumput laut kering. Hal ini sangat disayangkan, apalagi sampai saat ini Indonesia mengimpor produk jadi dalam jumlah dan nilai yang cukup besar (Tabel 1).

Terkait dengan usaha peningkatan nilai tambah dan mengurangi inefisiensi akibat kegiatan impor produk berbasis rumput laut, dalam beberapa tahun terakhir

Tabel 1. Volume dan nilai impor agar ke Indonesia 1995-1999

Table 1. Volume and value of agar import to Indonesia 1995-1999

\begin{tabular}{ccc}
\hline \multirow{2}{*}{ Tahun/Year } & \multicolumn{2}{c}{ Impor Agarlimported Agar } \\
\cline { 2 - 3 } & Volume (kg)/Volume (kg) & Nilai (US \$)/Value (US \$) \\
\hline 1995 & 495580 & 4711370 \\
1996 & 557658 & 3782948 \\
1997 & 614944 & 5555455 \\
1998 & 226216 & 2459961 \\
1999 & 599003 & 2773517 \\
\hline
\end{tabular}

Sumber/Source: BPS, 1999

2 Termasuk sejumlah faktor lain yang belum tercakup pada pemaparan di atas 
ini telah dikembangkan pabrik-pabrik pengolah. Sejauh ini, terdapat 22 pabrik pengolah rumput laut, yaitu 12 pabrik pengolah agar, 8 pabrik karagenan, 1 pabrik alginat, 1 pabrik pengolah sun chlorella. Pabrik-pabrik tersebut tersebar di Lampung, DKI Jakarta, Jawa Barat, Jawa Timur, Bali, Nusa Tenggara dan Sulawesi Selatan.

Meskipun potensi pasarnya besar, produksi dari ke-22 pabrik tersebut relatif kecil yaitu sekitar 6,295 ton/tahun. Khusus untuk pengolah agar-agar, dimana Gracillaria sp. merupakan salah satu jenis bahan bakunya, produk yang dihasilkan baru sebesar 888 ton/tahun. Hal ini terutama disebabkan oleh kesulitan bahan baku. Produksi bahan baku yang masih rendah dan persaingan dengan pengolah luar negeri dalam memperoleh bahan baku, menyulitkan pabrik-pabrik pengolah dalam negeri.

Masalah pada sisi pengolah ini dapat dipandang sebagai peluang bagi produsen Gracillaria $s p$., termasuk para petambak; namun demikian, realisasi pemanfaatan peluang tersebut harus mempertimbangkan kebutuhan Gracillaria sp. total yang dapat dipasok. Tabel 2 dapat dijadikan acuan untuk memperkirakan tambahan produksi yang dapat diusahakan melalui pengembangan budidaya Gracillaria sp.. Berdasarkan Tabel 2, tambahan ha/tahun (2,4 ton/ha/tahun Gracillaria sp. kering), maka akan diperoleh total produksi Gracillaria $s p$. basah sebanyak 5.256.120 ton/tahun (1.051.224 ton/ tahun Gracillaria sp. kering). Angka ini jauh melebihi keperluan tambahan produksi sebagaimana terlihat pada Tabel 2. Apabila hal ini terjadi, maka kegagalan industri Gracillaria sp. sebagaimana terjadi pada Eucheuma cottonii tak terelakkan.

Pengalaman kasus Eucheuma cottonii dan keterbatasan pasar relatif dibanding potensi produksi maksimal dari budidaya Gracillaria $s p$. tanpa pembatasan, membawa implikasi perlunya pengendalian. Total produksi dari semua sentra budidaya harus dibatasi sehingga produksi pertahun tidak lebih besar dari keperluan pasokan bahan baku, baik bagi pabrik pengolahah agar di dalam negeri maupun mancanegara.

\section{Perumusan Pola Manajemen Terpadu Usaha Gracillaria sp. di Tambak}

\section{Kebutuhan sinkronisasi dan optimalisasi produksi}

Hasil pengamatan variabel biofisik di petak-petak tambak di Kabupaten Karawang, yang dihubungkan dengan produktivitas lahan, menunjukkan bahwa

Tabel 2. Kebutuhan, produksi, dan tambahan kebutuhan Gracillaria sp. nasional, 2003

Table 2. National demand, production, and the required additional production of Gracillaria sp., 2003

\begin{tabular}{lc}
\hline $\begin{array}{l}\text { Produksi/kebutuhan/keperluan tambahan produksi/ } \\
\text { Production/demand/shortage }\end{array}$ & $\begin{array}{c}\text { Jumlah (ton/tahun)/ } \\
\text { Amount (tons/year) }\end{array}$ \\
\hline $\begin{array}{l}\text { Kebutuhan Pabrik Pengolah Dalam Negeri/ } \\
\text { Demand by Domestic Processors }\end{array}$ & 30.000 \\
Permintaan Luar Negeri/International demand & 15.000 \\
Produksi/Production & 8.000 \\
Tambahan produksi yang diperlukan/ & 37.000 \\
Additional production required & \\
\hline
\end{tabular}

Sumber/Source: Angkasa, (2003)

produksi yang diperlukan (peluang pasar) adalah 37 ton/tahun.

Pengembangan budidaya Gracillaria sp. pada semua tambak yang ada di seluruh Indonesia akan menghasilkan produk jauh melebihi kebutuhan yang ada. Menurut statistik, di Indonesia terdapat lahan tambak seluas 438,010 ha (Anon., 2003). Apabila diasumsikan bahwa tambak-tambak tersebut rata-rata menghasilkan Gracillaria sp. basah sebanyak 12 ton/ produksi Gracillaria sp. di tambak bervariasi tergantung pada variabel-variabel tersebut. Dalam konteks pengendalian produksi nasional, ini menunjukkan perlunya prioritasi dalam pemilihan lokasi-lokasi budidaya. Dalam hubungannya dengan keragaman produktivitas lahan, prioritasi diarahkan pada terlaksananya produksi nasional yang menciptakan nilai manfaat bersih (net benefit) sebesar-besarnya. Nilai manfaat bersih terbesar dapat direalisasikan 
melalui pengikutsertaan hanya lahan-lahan tambak yang memungkinkan usaha budidaya efisien dalam suatu skim pengembangan secara terpadu.

Tantangan besar yang dapat menghadang gagasan pengendalian adalah telah banyaknya daerah memprogramkan usaha budidaya Gracillaria sp. di wilayah masing-masing. Sinkronisasi program masing-masing wilayah merupakan suatu prasyarat yang tidak dapat ditawar untuk terciptanya keterpaduan dalam rangka pengendalian produksi dan optimalisasi usaha. Perlu dipikirkan oleh masingmasing daerah untuk mensinkronkan target-targetnya, terkait dengan pembagian kuota produksi, yang diperlukan untuk mencapai tingkat produksi bersama yang terjaga. Kuota dapat didasarkan atas beberapa kriteria objektif, misalnya: produktivitas lahan, biaya produksi, dan biaya transportasi/pemasaran. Reorientasi program dalam bentuk lain perlu dipertimbangkan oleh daerah yang memiliki lahan yang karena keterbatasannya (produktivitas lahan yang rendah, biaya produksi tinggi, dan sistem transportasi yang tidak efisien), tidak dapat bergabung dalam suatu skim produksi bersama. Reorientasi program dalam bentuk lain tersebut misainya perubahan tujuan pengembangan Gracillaria $s p$. dari tujuan komersialisasi rumput laut ke perbaikan kualitas air tambak.

Kapasitas biofilter Gracillaria sp. merupakan dasar bagi reorientasi program tersebut di atas. Sebagaimana teramati oleh petambak-petambak bandeng dan udang di Bekasi, kapasitas biofilter yang dimiliki Gracillaria sp. terbukti dapat meningkatkan produktivitas budidaya. Berdasarkan ini, daerahdaerah dengan lahan tambak yang kurang potensial untuk budidaya Gracillaria $s p$. dapat mempertimbangkan penanaman rumput laut jenis tersebut, bukan untuk tujuan pemasaran melainkan tujuan alternatif, yaitu untuk perbaikan produktivitas budidaya komoditas lain (bandeng/udang). Disamping tambahan keuntungan akibat peningkatan produksi bandeng/udang, para petambak dalam skema alternatif ini, masih memiliki kesempatan untuk meningkatkan keuntungan melalui penciptaan nilai tambah terhadap Gracillaria sp. yang dihasilkan, misalnya melalui kegiatan pengolahan sederhana untuk pasar lokal.

\section{Penyempurnaan pola pengembangan industri Gracillaria sp.}

Permasalahan diungkapkan di atas merupakan pijakan utama bagi kerangka rumusan pola manajemen pengusahaan Gracillaria $s p$., sebagaimana tertulis pada tujuan penelitian. Dari bahasan tersebut, beberapa kata kunci dapat disarikan dan dipertimbangkan untuk memberikan arah dari rumusan dimaksud. Kata-kata kunci tersebut adalah: (1) pengendalian produksi, (2) koordinasi/ keterpaduan, dan (3) dukungan pemerintah. Kata kunci 'pengendalian produksi' terkait dengan pembatasan pasokan total secara nasional dan pembagian kuota produksi antar daerah, yang diarahkan pada pencegahan produksi berlebih dan kejatuhan harga. Sementara itu, 'keterpaduan dikaitkan dengan perlunya koordinasi dan manajemen terpadu antar daerah, dalam rangka merealisasikan tujuan pengendalian produksi, seperti termaksud pada kata kunci pertama. Kata kunci ketiga, 'dukungan pemerintah', dikaitkan dengan perlunya fasilitasi pemerintah untuk terselenggaranya landasan kerjasama yang kokoh dan adil sehingga pelaku usaha, baik petambak maupun pengolah yang menampung hasil budidayanya, dapat memperkecil resiko usahanya masing-masing.

Selain mendasarkan pada hasil identifikasi masalah dan status pengusahaan Gracillaria sp. yang diperoleh dari kegiatan survei, kunjungan lapang dan konsultasi, perumusan pola manajemen pengusahaan Gracillaria sp. dalam tulisan ini juga mengoptimalkan keberadaan pola manajemen yang telah diusulkan dan diterapkan oleh lembaga penelitian atau institusi teknis sebelumnya, untuk tujuan yang lebih spesifik. Salah satu pola yang mempunyai keterkaitan terbanyak adalah yang diintroduksikan oleh Bank Indonesia (Gambar 1). Bank Indonesia memberikan titik berat pada penyehatan aspek finansial, baik secara langsung, untuk industri pengolahan/eksportir, yang diposisikan sebagai inti, maupun secara tidak langsung untuk produsen rumput laut, yang diposisikan sebagai petani plasma dalam suatu hubungan plasma-inti. Penyehatan aspek finansial secara langsung dilakukan melalui penyediaan bantuan kredit langsung sedangkan penyehatan secara tidak langsung dilakukan dengan penguatan permodalan yang disalurkan melalui pihak ketiga. Kerjasama menurut pola ini diperkuat dengan nota kesepahaman yang difasilitasi bank yang diposisikan sebagai penyedia kredit, dan melalui penyertaan para petambak dalarn keanggotaan koperasi.

Secara umum, poia tersebut cukup baik untuk memfasilitasi penjaminan kerjasama antara petambak dan pengolah dan dapat mengurangi resiko usaha kedua belah pihak. Tetapi, diskusi dengan pelaku usaha menunjukkan bahwa solusi pola tersebut terlalu berskala besar (nasional) sehingga bayangan kegagalan yang pernah dihadapi pelaku usaha pada era pengembangan Eucheuma cottonii, tetap menjadi kekhawatiran dalam pengembangan Gracillaria $s p$. Dalam hal ini, meskipun dalam jangka pendek pola tersebut mampu menyehatkan kinerja usaha di 
sebagian sentra, tidak ada jaminan bahwa kinerja yang baik tersebut dapat bertahan lama karena pola tersebut tidak mengandung komponen yang memungkinkan penngendalian jumlah unit usaha pada tingkat yang efisien. Karenanya, pola Bank Indonesia ini dapat dipandang sebagai modal yang baik untuk membangun pola yang lebih komprehensif, yang perlu disempurnakan untuk mengakomodasikan ekonomis. Termasuk kelompok biofisik adalah ketersediaan nutrien untuk pertumbuhan rumput laut, faktor penghambat yang berasal dari polutan dan logam, dan salinitas (yang dipengaruhi oleh curah hujan), serta penurunan kadar polutan yang diakibatkan oleh penanaman Gracillaria sp. Pada kelompok sosio-ekonomis, hal utama yang relevan adalah menyangkut status sosial ekonomi

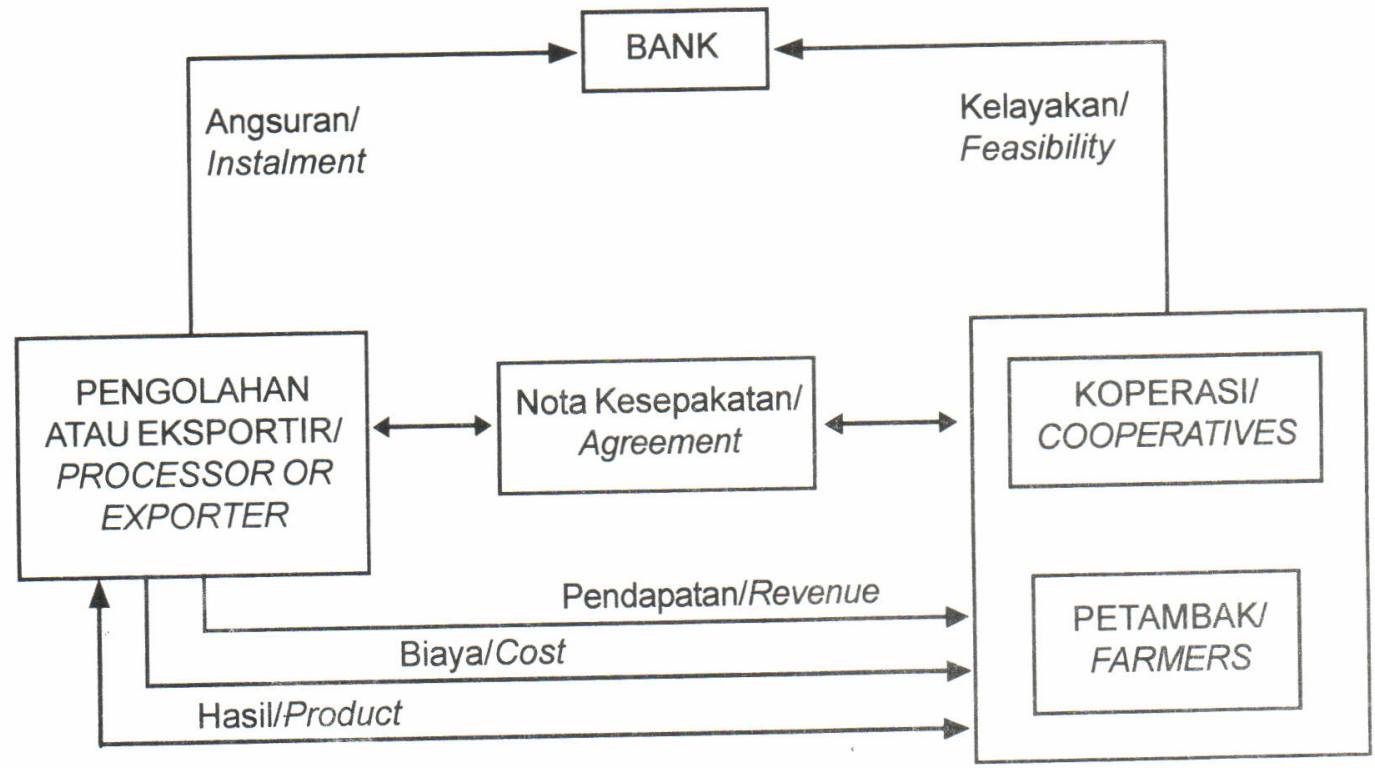

Gambar 1. Pola pengembangan industri Gracillaria sp. versi Bank Indonesia.

Figure 1. Model for Gracillaria sp. industry development of Bank Indonesia version.

permasalahan lain yang juga teridentifikasi dalam penelitian ini, termasuk masalah pengendalian produksi dan dan keterpaduan

Dalam konteks perumusan pola pengembangan Gracillaria sp. ini, koordinasi merupakan komponen prasyarat untuk mengendalikan produksi (total pasokan). Terpenuhinya prasyarat tersebut memungkinkan upaya penanggulangan kesulitan pasokan bahan baku yang dihadapi oleh pengolah, sebagaimana telah dibahas terdahulu. Melalui koordinasi, daerah-daerah dengan lahan berpotensi dapat mengkompromikan berbagai hal terkait dengan pengusahaan Gracillaria sp., penjadwalan dan besarnya kontribusi produksi masing-masing untuk mencapai total produksi yang ditentukan sebelumnya, yang akan diimplementasikan ke dalam suatu program terpadu.

Dalam operasionalnya, kompromi menyangkut penjadwalan dan penentuan 'kuota' produksi tersebut di atas akan mempersyaratkan ketersediaan dua jenis informasi penting, yaitu informasi biofisik dan sosio- pembudidaya, kelayakan usaha terpadu yang melibatkan berbagai lokasi budidaya yang tersebar, dan kontinuitas pasokan kepada pabrik pengolah atau pemasar.

Penyertaan dua informasi penting dalam skenario tersebut diusulkan berdasarkan hasil-hasil pengamatan aspek-aspek terkait yang diperoleh dalam penelitian ini. Hasil pengamatan aspek teknis, yang mengkaitkan kondisi biofisik dan produktivitas (Purnomo et al., 2003), mengisyaratkan relevansi suatu 'seleksi' terhadap kandidat peserta program pengusahaan Gracillaria sp. terpadu, yang dalam hal ini dapat diartikan sebagai propinsi atau kabupaten potensial. Berdasarkan itu, data variabel biofisik dari masing-masing daerah kandidat dapat dipergunakan untuk memprediksi produktivitas dan produksi masingmasing, sehingga dari sudut pandang ini pemilihan kandidat terbaik dapat dilaksanakan. Namun demikian, berdasarkan hasil penggalian data dan informasi aspek pemasaran dan kelembagaan (Purnomo et al., 2003), prediksi biofisik tersebut tidak 
cukup untuk menentukan lokasi-lokasi terbaik karena beberapa daerah dengan produktivitas lahan tinggi diperkirakan tidak akan mampu memasok bahan baku ke lokasi pengolah agar-agar dengan harga yang bersaing karena tingginya biaya transportasi dan permasalahan yang terkait dengan aspek kelembagaan. Beberapa wilayah di Kawasan Timur Indonesia merupakan contoh untuk lokasi dengan kondisi tersebut (Purnomo et al., 2003) karena biaya transportasi dari wilayah-wilayah tersebut ke lokasilokasi pabrik pengolah di Pulau Jawa dapat mencapai 1,5-2 kali lipat, dibanding biaya transportasi dari lokasi-lokasi di Sumatera dan Bali ke tujuan yang sama.

Selain pengendalian dan distribusi produksi, hal penting lain yang teridentifikasi sebagai komponen penting dalam pola pengembangan Gracillaria sp. adalah mekanisme yang memungkinkan terjalinnya kerjasama/koordinasi antar daerah. Melalui mekanisme tersebut, dinamika dari variabel-variabel terkait di masing-masing daerah dapat dikomunikasikan secara periodik oleh daerah-daerah/ sentra budidaya dan pabrik pengolah. Dengan demikian, penyesuaian-penyesuaian, termasuk mengenai tingkat produksi, dapat dilakukan secara baik. Mekanisme tersebut misalnya dapat dimanifestasikan dalam aplikasi sebuah model sistem informas ${ }^{3}$ (Purnomo et al., 2003). Sistem informasi dalam konteks ini dimaksudkan sebagai suatu rangkaian simpul data yang didesain sedemikian rupa untuk memfasilitasi pengambilan keputusankeputusan yang didasarkan pada informasi yang utuh, yang mencakup laporan-laporan dari semua sentra budidaya, pabrik pengolah, dan sumber informasi lain yang relevan. Bagi sentra-sentra budidaya, keputusan dimaksud misalnya menyangkut besarnya jumlah pasokan yang harus mereka sediakan bagi pabrik pengolah pada suatu saat dan pada periode-periode yang lain; sementara itu, bagi pabrik pengolah keputusan tersebut misalnya menyangkut penyesuaian tingkat produksi agar-agar, pengisian stok, dan rencana pemasarannya.

Berdasarkan bahasan di atas, bentuk penyempurnaan pola pengembangan Gracillaria sp. yang diusulkan melalui penelitian ini adalah sebagaimana dapat dilihat pada Gambar 2; sebuah rumusan yang menggabungkan pola yang telah ada/ berjalan dengan berbagai masukan baru. Pola tersebut

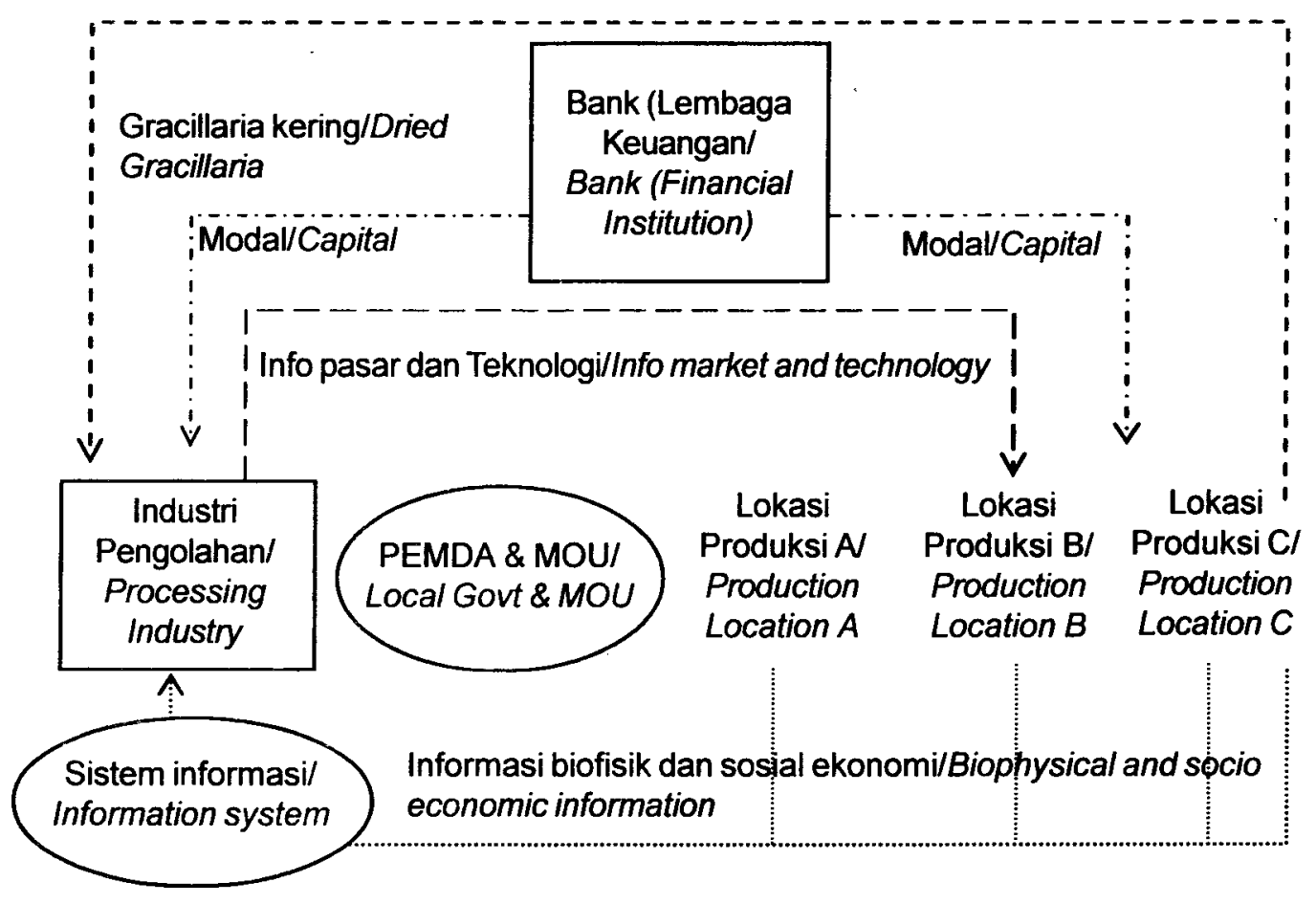

Gambar 2. Pola perbaikan pengembangan industri Gracillaria sp.

Figure 2. Improved model for the development of Gracillaria sp. industry.

Sebagai bahan exercise, penelitian ini mengembangkan sebuah model sistem informasi manajemen Gracillaria sp. diistilahkan sebagai GIMS (Gracillaria Information Management System). 
mengilustrasikan sebuah kerjasama usaha, dimana jalinan informasi, hubungan keuangan, dan arus barang, mengikat setiap unit usaha yang tergabung dalam kerjasama dimaksud.

\section{Penanganan lahan tambak yang kurang potensial}

Gambar 2 mengisyaratkan adanya implikasi negatif berupa dislokasi sebagian tambak; artinya, sebagian tambak akan tersisihkan dari manajemen terpadu yang didesain untuk pengembangan usaha secara nasional. Tambak-tambak berada pada lokasi-lokasi 'marjinal', yang kondisi biofisik maupun sosio-ekonomisnya tidak lebih baik dibanding lokasi-lokasi peserta kerjasama usaha Gracillaria sp. nasional terpadu.

Mengingat bahwa karakteristik biofilter Gracillaria $s p$. dapat berdampak pada perbaikan kualitas lingkungan perairan budidaya di tambak, implikasi negatif tersebut di atas dapat diperkecil apabila tujuan penanaman di lokasi-lokasi marjinal difokuskan pada perbaikan lingkungan perairan. Dengan demikian, dampak positif yang diharapkan, yaitu peningkatan pendapatan petambak dapat dicapai karena perbaikan kualitas air tambak akan meningkatkan produktivitas budidaya bandeng dan atau udang, dua komoditas yang selama ini umum diusahakan. Ini merupakan sebuah implikasi kebijakan dari pola pengembangan sebagaimana diusulkan dalam penelitian ini. Konsisten dengan pengamatan petambak di Bekasi, penelitian ini mendapatkan indikasi telah terjadinya peningkatan produktivitas budidaya udang yang ditumpangsarikan dengan Gracillaria sp. . Prediksi yang didasarkan pada pengalaman petambak dalam melakukan pendugaan biomasa yang dibudidayakan, menunjukkan bahwa penanaman Gracillaria sp. di Cilamaya dan Rengasdengklok terbukti mempercepat pertumbuhan bandeng dan udang sampai tingkat tertentu.

Secara diagramatis, hasil pengamatan ${ }^{4}$ di ketiga lokasi dapat diilustrasikan dengan tampilan Gambar 3. Meskipun pada akhirnya udang tumpangsari tidak mampu menahan imbas bencana yang pada saat penelitian menimpa semua areal tambak di wilayah dimana tambak-tambak tersebut berada, pengamatan bersama dengan petambak kooperator menunjukkan bahwa udang di tambak-tambak tersebut merupakan yang terakhir mengalami imbas bencana, dibanding tambak-tambak udang di sekitarnya.

Sejauh ini, logika yang dipandang mendekati kebenaran adalah bahwa kematian udang pada saat pertumbuhan mencapai 2 bulan diakibatkan oleh

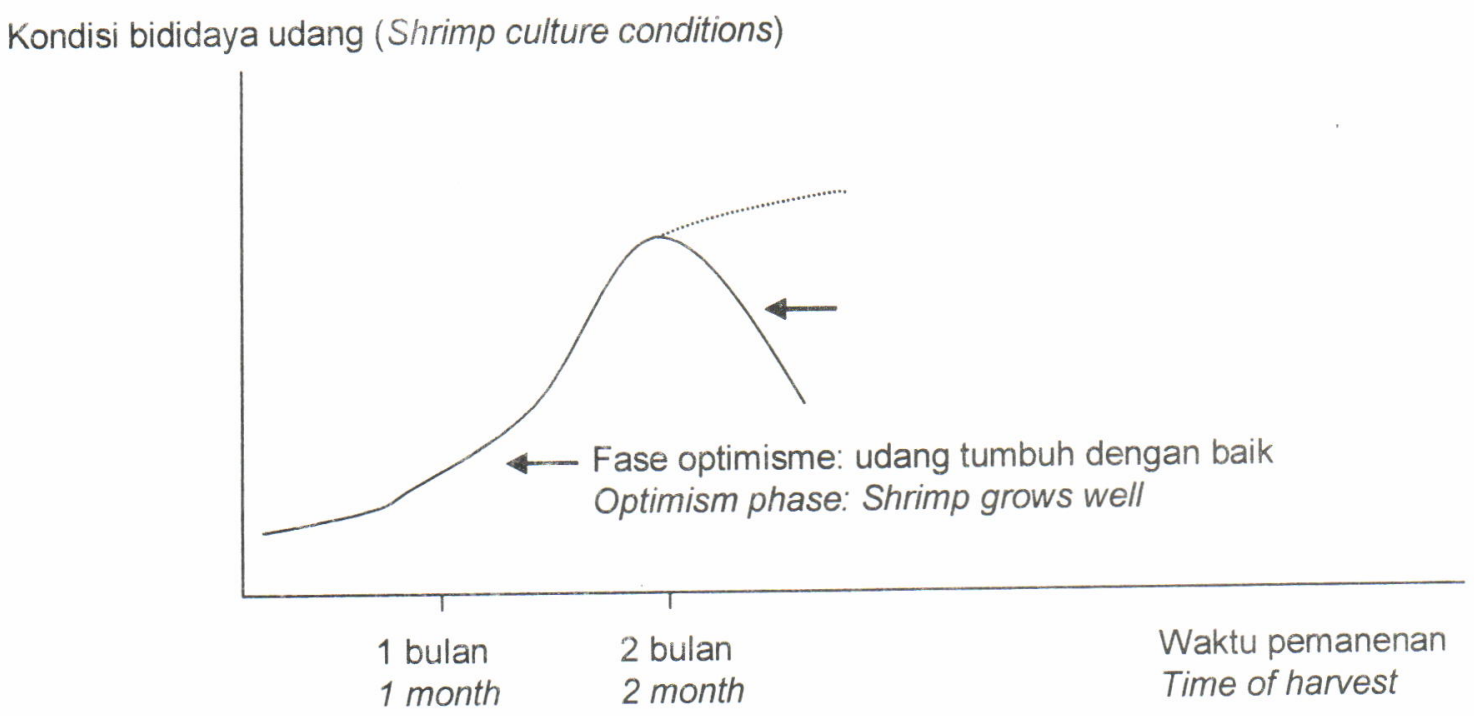

Gambar 2. Perkembangan udang tumpangsari dengan Gracillaria sp.

Figure 2. The development of shrimp policultured with Gracillaria sp.

Catatan/Note: Didasarkan atas pengamatan kualitatif oleh petambak/

Based on qualitative observation by brackish-water farmers

\footnotetext{
4 Pengamatan ini tidak memberikan tampilan kuantitatif tentang biomasa udang yang ditumpangsarikan dengan Gracillaria sp. karena terjadi kematian udang sebelum saat pemanenan dan penimbangan biomasa yang telah direncanakan sebelumnya
} 
belum cukupnya densitas Gracillaria sp. di dalam tambak, untuk menopang pertumbuhan udang pada fase lanjut. Melengkapi implikasi kebijakan seperti terungkap di atas, fakta yang diperoleh dari penelitian yang bersirat sosial ekonomis ini membawa implikasi ilmiah positif berupa terbukanya ruang untuk penelitian lanjutan yang bersifat teknis. Penelitian teknis tersebut diharapkan dapat menjawab kebutuhan informasi ilmiah tentang: hubungan antara densitas Gracillaria $s p$. dengan jurnlah udang yang dibudidayakan, yang dapat pula dikaitkan dengan penentuan saat yang tepat untuk melakukan penebaran benih udang dalam periode pembudidayaan Graciliaria sp.

\section{KESIMPULAN DAN IMPLIKASI KEBIJAKAN}

Pembudidayaan Gracillaria sp. berpotensi meningkatkan keuntungan petambak sebesar Rp. 6,9 - 21,3 juta/ha/tahun sekaligus mengatasi masalah pasokan yang dihadapi oleh industri agar. Namun demikian, diperkirakan bahwa perkembangan usaha tersebut terkendala oleh kekhawatiran petambak akan terjadinya pasok lebih (oversupply), yang akan diikuti oleh kemerosotan harga jual produk. Solusi yang ditawarkan melalui makalah ini adalah pengendalian produksi melalui manajemen usaha yang dilakukan secara terpadu, yaitu melalui sistem kuota budidaya yang mencakup hanya lokasi-lokasi paling potensial untuk mencapai tingkat produksi total tidak lebih dari kebutuhan pasar.

Lokasi-lokasi lain yang kurang potensial disarankan untuk mengembangkan budidaya Gracillaria $s p$. dengan memfokuskan pada tujuan alternatif, yaitu untuk perbaikan produktivitas budidaya komoditas lain (bandeng/udang). Hasil penelitian ini juga membuka peluang untuk dilakukannya penelitian aspek teknis yaitu menyangkut hubungan antara kepadatan Gracillaria sp. dan produktivitas bandeng atau udang yang dibudidayakan secara tumpangsari

Implikasi penelitian ini adalah: (1) Pada sisi kebijakan, direkomendasikan adanya pengelolaan usaha Gracillaria $s p$. secara terpadu yang hanya menyertakan tambak-tambak paling potensial, baik secara fisik maupun ekonomis dan direkomendasikan bahwa tambak selebihnya diarahkan pada penanaman Gracillaria $s p$. untuk tujuan perbaikan kualitas air budidaya bandeng/udang, (2) Pada sisi ilmiah, implikasi yang dihasilkan berupa terbukanya ruang untuk penelitian lanjutan yang bersifat teknis untuk mengetahui hubungan antara densitas Gracillaria sp. dengan jumlah udang yang dibudidayakan, yang dapat pula dikaitkan dengan penentuan saat yang tepat untuk melakukan penebaran benih udang dalam periode pembudidayaan Gracillaria sp. .

\section{DAFTAR PUSTAKA}

Angkasa, 2003. Teknologi Budidaya dan Pasca Panen Rumput Laut (Materi Pelatihan). Balai Inkubator Teknologi Badan Pengkajian dan Penerapan Teknologi.

Anonim, 2003. Sistem Informasi Pengembangan Usaha Kecil. Bank Indonesia.

Kusnendar, E., 2002. Strategi Pengembangan Budidaya Rumput Laut. Prosiding Forum Rumput Laut. Jakarta, 6 Agustus 2002. Pusat Riset Pengolahan Produk dan Sosial Ekonomi Kelautan dan Perikanan, Badan Riset Kelautan dan Perikanan. DKP. Jakarta.p. 3958.

Ma'ruf, W.F., 2002. Prospek Pengembangan Industri Pengolahan Rumput Laut. Prosiding Forum Rumput Laut. Jakarta, 6 Agustus 2002. Pusat Riset Pengolahan Produk dan Sosial Ekonomi Kelautan dan Perikanan, Badan Riset Kelautan dan Perikanan. DKP. Jakarta. p. 17-31

Purnomo, A.H., Aji, N., Irianto, H.E., Nasution, Z., Hikmayani, Y., Erlina, M.D., Saptanto, S., Dolaria, N. dan Carkipan. 2003. Manajemen Terpadu Pengembangan Budidaya Gracillaria di Tambak dalam Upaya Peningkatan Ekonomi Masyarakat Petani Tambak (Laporan Teknis). Pusat Riset Pengolahan Produk dan Sosial Ekonomi Kelautan dan Perikanan.

Satgas Tambak, 1994. Alternatif Solusi Masalah Budidaya Tambak Udang di Jawa. Dep. Pertanian, Direktorat Jenderal Perikanan, Jakarta.

Singarimbun, M. dan Effendi, S. 1989. Metode Penelitian Survei. LP3ES. Jakarta.

STPP. 2002. Uji Coba Budidaya Rumput Laut di Tambak. Leaflet. Sekolah Tinggi Penyuluh Pertanian. Bogor. $6 \mathrm{pp}$.

Taukhid, A., Suwidah, Sudradjat, A., Taufik, P., Hikmayani, Y. dan Muniyati, 2001. Kebijakan Pengelolaan Tambak Udang di Pantai Utara dan Selatan Jawa. Analisis Kebijakan Pembangunan Perikanan. Pusat Riset Pengolahan Produk dan Sosial Ekonomi Kelautan dan Perikanan, Jakarta.

Wahyuni, M. 2003. Peran Bioteknologi dalam Pengolahan Produk Perikanan. 2004. IPB. 10-20 pp

Zafran, 1992. Pencegahan Penyakit Kunang-Kunang pada Larva Udang Windu. Seminar Upaya Penanggulangan Benur di Hatchery. Surabaya 20 Februari 1992. 
Lampiran 1. Ringkasan perbandingan status perkembangan, profitabilitas dan kondisi teknis budidaya Gracillaria sp. di berbagai lokasi

Appendix 1. Summary of comparison of development status, profitability, and technical condition of Gracillaria sp. culture in various locations

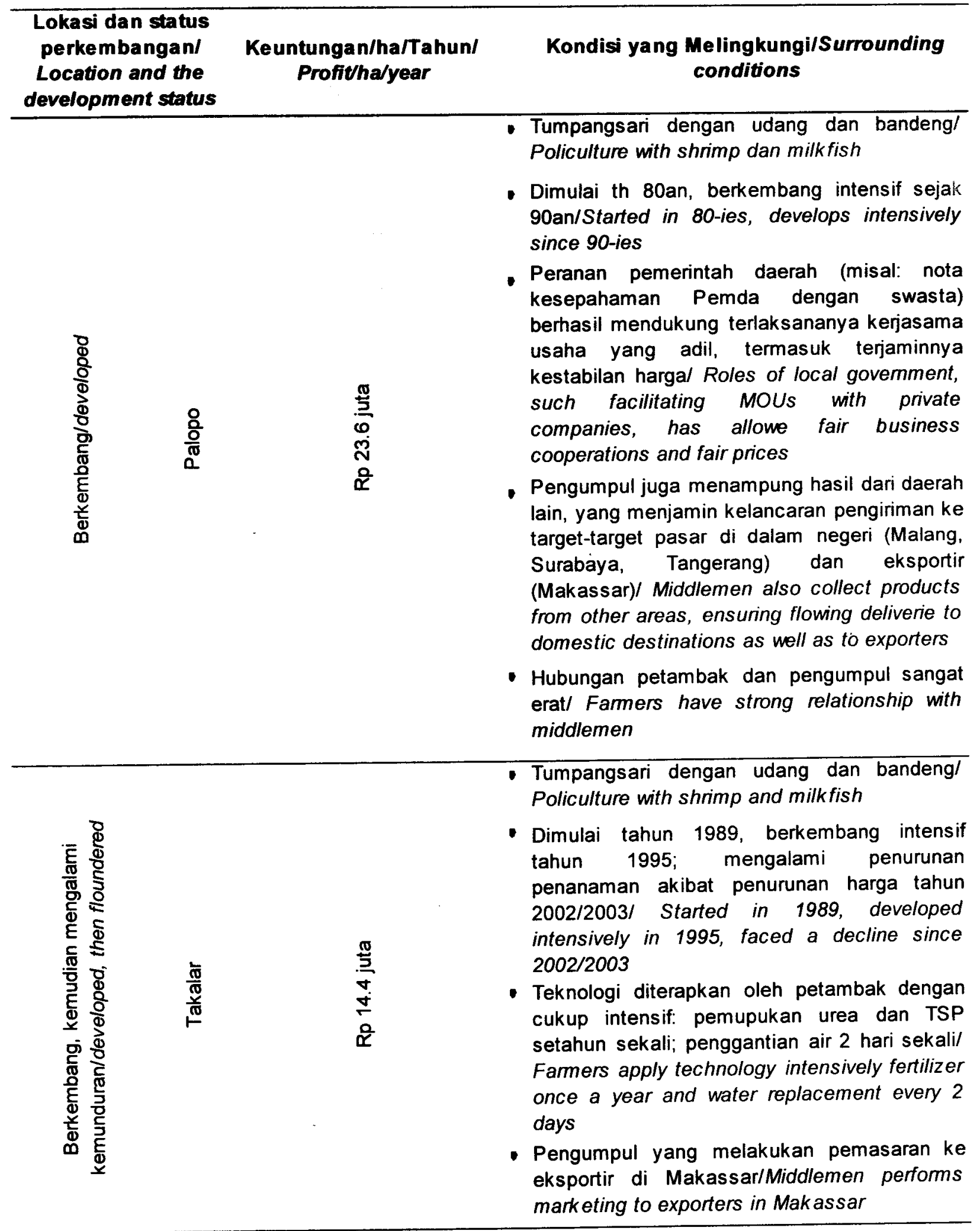


Lampiran 1. Ringkasan perbandingan status perkembangan, profitabilitas dan kondisi teknis budidaya Gracillaria sp. di berbagai lokasi (lanjutan)

Appendix 1. Summary of comparison of development status, profitability, and technical condition of Gracillaria sp. culture in various locations (continued)

\begin{tabular}{|c|c|c|c|}
\hline \multicolumn{2}{|c|}{$\begin{array}{l}\text { Lokasi dan status } \\
\text { perkembanganl } \\
\text { Location and the } \\
\text { development status }\end{array}$} & \multirow{2}{*}{ 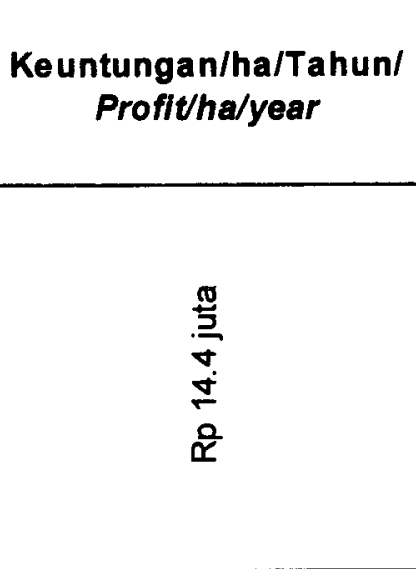 } & \multirow{2}{*}{$\begin{array}{l}\text { Kondisi yang Melingkungi/Surrounding } \\
\text { conditions } \\
\text { - Tidak ada kerjasama formal antara petambak } \\
\text { dengan pembeli yang difasilitasi pemerintah, } \\
\text { sebagaimana terjadi di Palopo/No formal, } \\
\text { government facilitated collaboration between } \\
\text { farmers and buyers, as occurred in Palopo } \\
\text { - Petambak kadang mendapatkan modal kerja dari } \\
\text { pengumpul/Farmers sometimes receive working } \\
\text { capital from middlemen }\end{array}$} \\
\hline 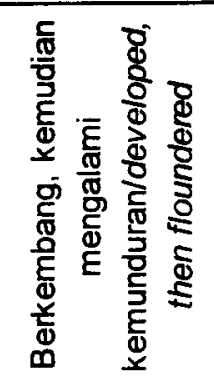 & $\begin{array}{l}\frac{\bar{\sigma}}{\pi} \\
\frac{\pi}{\sigma} \\
⺊\end{array}$ & & \\
\hline $\begin{array}{l}\frac{8}{8} \\
\frac{0}{0} \\
\frac{0}{0} \\
\frac{0}{0} \\
\frac{0}{0} \\
\frac{1}{0} \\
\frac{0}{0} \\
\frac{0}{0} \\
\frac{1}{0} \\
0\end{array}$ & 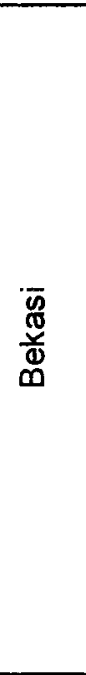 & 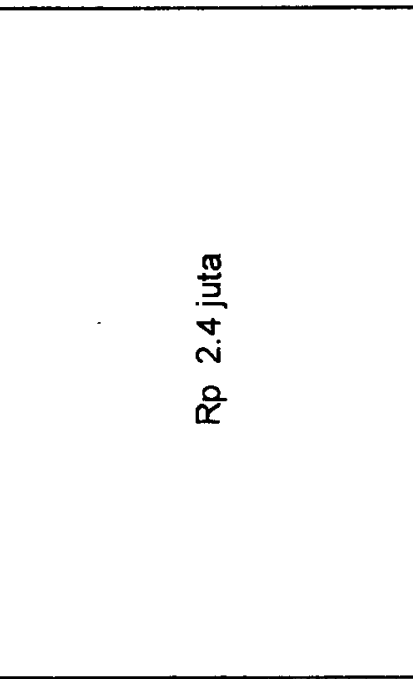 & $\begin{array}{l}\text { - Tumpangsari dengan udang dan bandeng } \\
\text { bandeng/policulture with shrimp and milkfish } \\
\text { - Dimulai tahun 2001/started in } 2001 \\
\text { - Teknologi diterapkan dengan baik, termasuk } \\
\text { penggantian air dan pemupukan urea sekali } \\
\text { seminggu/Technology, including fertilizing and } \\
\text { water circulating, is applied well } \\
\text { - Kerjasama Kelompok Tani dengan Pengusaha, } \\
\text { didukung oleh pemerintah setempat; dalam hal } \\
\text { ini pengusaha, tanpa fasilitasi pengumpul, } \\
\text { menampung hasil panen secara langsung untuk } \\
\text { diolah/Collaboration between farmers and } \\
\text { processors are supported by local government; } \\
\text { farmer, with no middlemen, sell the products } \\
\text { directly to processors }\end{array}$ \\
\hline 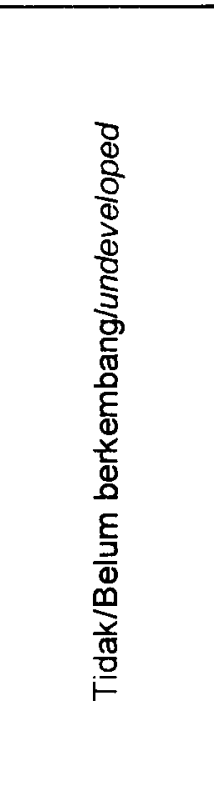 & 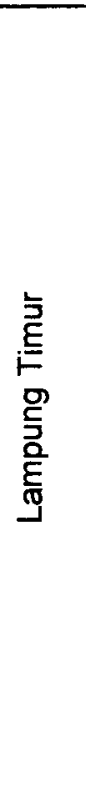 & 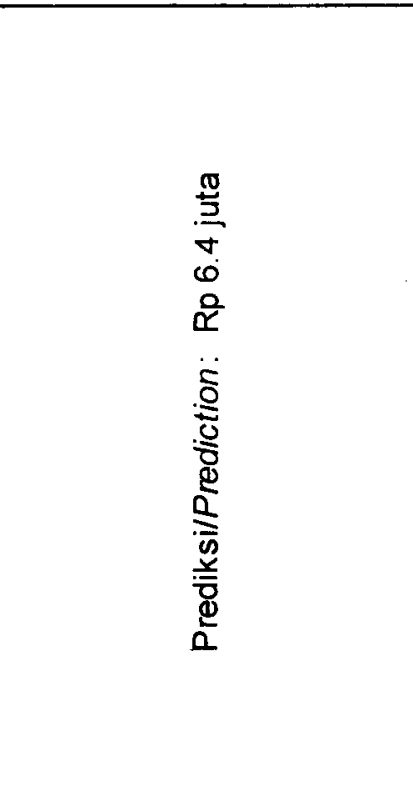 & $\begin{array}{l}\text { - Polikultur dengan udang dan bandeng } \\
\text { bandeng/policulture with shrimp and milkfish } \\
\text { - Dimulai tahun } 97 / 98 \text { dengan penanaman } \\
\text { percobaan, tetapi tidak ada kemajuan berarti } \\
\text { dalam beberapa tahun/started in } 97 / 98 \text { with trial } \\
\text { cultivation buthas so far made no significant } \\
\text { progress } \\
\text { - Uji coba yang lebih serius dilakukan pada tahun } \\
2002 \text { oleh pemerintah setempat bekerjasama } \\
\text { dengan STPP/a more serious trial was carried } \\
\text { out by local govt in collaboration with the } \\
\text { Institute of Fisheries, STPP } \\
\text { - Meski ujicoba menunjukkan sisi teknis yang } \\
\text { positif, petambak belum menindaklanjuti karena } \\
\text { khawatir akan resiko pemasarannya/ Despite } \\
\text { positive technical results, this trial has brought } \\
\text { no significant impact because of the farmers' } \\
\text { concem overmarketing nisk }\end{array}$ \\
\hline
\end{tabular}


Lampiran 1. Ringkasan perbandingan status perkembangan, profitabilitas dan kondisi teknis budidaya Gracillaria sp. di berbagai lokasi (lanjutan)

Appendix 1. Summary of comparison of development status, profitability, and technical condition of Gracillaria sp. culture in various locations (continued)

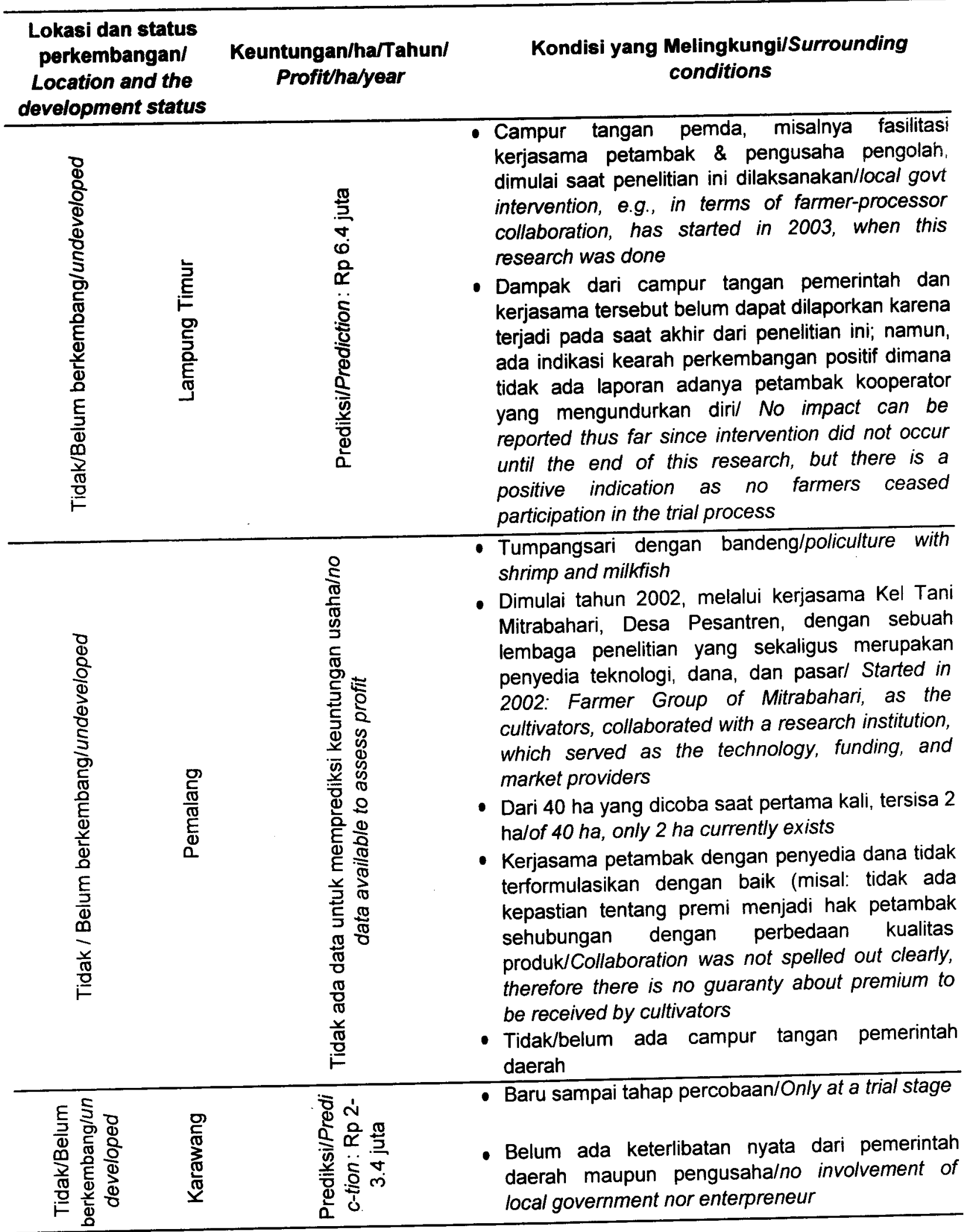


A.H. Pumomo, Hikmayani, Y., Nasution, Z. dan Irianto, H.E. 